\title{
PENGARUH PUBLIC OWNERSHIP DAN GROWTH OPPORTUNITY TERHADAP LEVERAGE DAN FUTURE EARNINGS RESPONSE COEFFICIENT
}

\author{
Henny \\ Fakultas Ekonomi, Universitas Tarumanagara Jakarta \\ henny_untar3@yahoo.com
}

\begin{abstract}
The purpose of the study to obtain empirical evidence regarding (1) The direct effect to Future Earnings Response Coefficient: (a) Public Ownership positive effect on Future Earnings Response Coefficient, (b) Growth Opportunity positive effect on Future Earnings Response Coefficient, (c) Leverage negatively affect Future Earnings Response Coefficient. (2) The indirect effect to Future Earnings Response Coefficient, through Leverage: (a) Public ownership through a leverage effect on Future Earnings Response Coefficient, (b) Growth Opportunity through a leverage effect on Future Earnings Response Coefficient. (3) The effect of direct and indirect effect that has the most significant effect on Future Earnings Response Coefficient. The method used is the Structure Equation Model (SEM) using AMOS 22, 2008-2011 with the data used from the years 2007 to 2014, bringing the total number of samples observed data 273 manufacturing companies. The results showed a variable that has a direct effect to Future Earnings Response Coefficient is variable Public Ownership, Growth Opportunity and Leverage, while the variable that most effect directly to Future Earnings Response Coefficient is variable Leverage. The variables that have an indirect effect to Future Earnings Response Coefficient through leverage is variable of Growth Opportunity, so variable of Growth Opportunity through this leverage that most have indirect effect on Future Earnings Response Coefficient.
\end{abstract}

Keywords: Future Earnings Response Coefficient, Growth Opportunity, Leverage, and Public Ownership

\section{PENDAHULUAN}

Latar Belakang

Perusahaan menerbitkan laporan keuangan berguna untuk memberikan gambaran kondisi perusahaan kepada para pemegang kepentingan (stakeholder). Laporan keuangan ini harus jelas dan informatif bagi para pembaca laporan keuangan tersebut, sehingga bisa dijadikan pengambilan keputusan bagi stakeholder. Investor yang merupakan salah satu dari stakeholder akan memberikan respon yang kuat terhadap informasi baik atau buruk dalam laba untuk perusahaan tertentu dibandingkan dengan perusahaan lainnya. Sehubungan dengan hal tersebut, maka memprediksi laba masa depan dengan Future Earnings Response Coefficient (FERC) merupakan informasi yang berguna bagi investor.

Future Earnings Response Coefficient dipengaruhi oleh faktor kepemilikan publik (Public Ownership) dan kesempatan pertumbuhan (Growth Opportunity). Public Ownership yang besar akan mempengaruhi Future Earnings Response Coefficient, karena dengan banyak proporsi Public Ownership di perusahaan, berarti perusahaan tersebut dipercaya oleh masyarakat dapat memberikan laba kejutan di masa depan yaitu Future Earnings Response Coefficient, hal ini memberikan signal yang positif bagi investor. Sedangkan Growth Opportunity yang besar di proksi dengan kenaikan penjualan setiap tahunnya akan memberikan peningkatan laba kejutan di masa depan bagi investor dan merupakan signal positif bagi investor di pasar modal yang pada akhirnya dapat meningkatkan harga saham perusahaan (Murwaningsari, 2013).

Leverage merupakan variabel intervening dalam penelitian ini, karena Leverage berhubungan dengan Public Ownership, maka Public Ownership akan melakukan koalisi untuk memiliki hak suara yang cukup untuk mempunyai kekuatan yang relatif signifikan. Berdasarkan hasil penelitian yang dilakukan oleh Ariyanto (2002) dan Lestari \& Hermanto (2015) menunjukkan bahwa pemegang saham publik berpengaruh negatif terhadap struktur modal. Leverage juga berhubungan dengan Growth Opportunity yang memberikan asset yang besar kepada 
perusahaan, sehingga dengan adanya asset yang besar tersebut dapat memberikan jaminan atas pinjaman yang diberikan pihak lain kepada perusahaan (Shaheen \& Malik, 2012). Sehubungan dengan pinjaman yang diberikan, maka proporsi Public Ownership dan Growth Opportunity, yang diprediksikan akan memberikan manfaat berupa laba kejutan di masa depan yaitu Future Earnings Response Coefficient.

Penelitian ini berbeda dengan penelitian Murwaningsari (2013) di variabel independennya yaitu adanya corporate governance dan berbeda dari penelitian Pradhana \& Murwaningsari (2014) yang juga menggunakan corporate governance (board of commsioner, board size, dan internal auditor), namun corporate governance yang digunakan dalam penelitian ini adalah struktur kepemilikan yaitu kepemilikan publik (public ownership) diduga memiliki pengaruh positif terhadap Future Earnings Response Coefficient. Hal ini dilakukan sesuai dengan rekomendasi penelitian Murwaningsari (2013) untuk penelitian selanjutnya memasukkan Public Ownership. Pemilihan variabel Public Ownership karena variabel ini belum pernah dilakukan pada penelitian sebelumnya dan juga Public Ownership menurut Lestari \& Hermanto (2015) dapat mencegah terjadinya biaya konflik agensi yang tinggi, sehingga tidak perlu melakukan pinjaman dari luar yang lebih berisiko.

Tujuan penelitian ini adalah untuk memperoleh bukti empiris mengenai (1) Pengaruh langsung ke Future Earnings Response Coefficient: (a) Public Ownership berpengaruh positif terhadap Future Earnings Response Coefficient, (b) Growth Opportunity berpengaruh positif terhadap Future Earnings Response Coefficient, (c) Leverage berpengaruh negatif terhadap Future Earnings Response Coefficient. (2) Pengaruh tidak langsung ke Future Earnings Response Coefficient, melalui Leverage: (a) Public Ownership melalui Leverage berpengaruh terhadap Future Earnings Response Coefficient, (b) Growth Opportunity melalui Leverage berpengaruh terhadap Future Earnings Response Coefficient. (3) Pengaruh langsung dan pengaruh tidak langsung yang memiliki pengaruh paling signifikan terhadap Future Earnings Response Coefficient.

\section{Future Earnings Response Coefficient (FERC)}

Future Earnings Response Coefficient merupakan pendekatan yang dikembangkan oleh Collins et al. (1994) untuk menguji banyaknya informasi mengenai future earnings tercermin dalam perubahan current earnings. Future Earnings Response Coefficient inilah yang sering digunakan untuk memprediksi laba masa depan atau yang biasa disebut dengan laba kejutan di masa depan. Faktor-faktor yang mempengaruhi Future Earnings Response Coefficient adalah Public Ownership dan Growth Opportunity. Variabel lain yang mempengaruhi adalah variabel Audit Quality (Hussainey, 2009) dan Long Term Investment (Chou et al., 2012), yang dijadikan variabel kontrol dalam penelitian ini.

\section{Leverage}

Rasio leverage adalah mengukur seberapa besar perusahaan dibiayai dengan utang. Penggunaan utang yang terlalu tinggi akan membahayakan perusahaan karena perusahaan akan masuk dalam kategori extreme leverage (Fahmi, 2014:127). Faktor-faktor yang mempengaruhi leverage ini yang dijadikan variabel kontrol yaitu variabel Firm Size (Indrajaya et al., 2011; dan Murwaningsari, 2013) dan variabel Fixed Assets (Prasetiono \& Pujiani, 2012; dan Murwaningsari, 2013 \& 2014).

\section{Public Ownership dan Leverage}

Pemegang saham publik akan melakukan koalisi untuk memiliki hak suara yang cukup untuk mempunyai kekuatan yang relatif signifikan. Perbedaannya dengan pemegang saham mayoritas adalah ketika melakukan koalisi antara pemegang saham publik maka masing-masing individu 
harus mengeluarkan biaya penggalangan koalisi. Berdasarkan hasil penelitian yang dilakukan oleh Ariyanto (2002), Lestari \& Hermanto (2015), dan Chen et al. (2014) menunjukkan bahwa pemegang saham publik berpengaruh negatif terhadap struktur modal. Kondisi ini menunjukkan semakin tinggi tingkat pemegang saham publik akan menurunkan tingkat struktur modal yang dimiliki oleh perusahaan. Hal ini dilakukan untuk meningkatkan laba melalui kinerja perusahaan sehingga tidak perlu melakukan pinjaman dari luar yang lebih berisiko. Berdasarkan hal tersebut di atas, maka hipotesis yang dapat diajukan:

\section{$\mathrm{H}_{1}$ : Public Ownership berpengaruh negatif terhadap Leverage}

\section{Growth Opportunity dan Leverage}

Growth Opportunity yang memberikan asset yang besar kepada perusahaan, sehingga dengan adanya asset yang besar tersebut dapat memberikan jaminan atas pinjaman yang diberikan pihak lain kepada perusahaan (Oetama et al., 2008; Shaheen \& Malik, 2012; Murwaningsari, 2013). Sehubungan dengan pinjaman yang diberikan, maka kesempatan perusahaan untuk meningkatkan Growth Opportunity. Hal ini berarti kesempatan pertumbuhan yang semakin tinggi akan mendorong perusahaan untuk melakukan investasi dengan mengandalkan pendanaan melalui hutang yang lebih besar. Berdasarkan hal tersebut di atas, maka hipotesis yang dapat diajukan:

\section{$\mathrm{H}_{2}$ : Growth Opportunity berpengaruh positif terhadap Leverage}

\section{Public Ownership dan Future Earnings Response Coefficient}

Public Ownership yang memberikan kesempatan perusahaan meningkatkan kepercayaan publik dalam proporsi Public Ownership, sehingga dapat memberikan jaminan atas pinjaman yang diberikan pihak lain kepada perusahaan (Luo et al., 2006; Firth et al., 2007; Cohen \& Langberg, 2009; Huang \& Wright, 2015). Sehubungan dengan kesempatan perusahaan meningkatkan kepercayaan publik dalam proporsi Public Ownership, yang diprediksikan akan memberikan manfaat berupa laba kejutan di masa depan yaitu Future Earnings Response Coefficient. Berdasarkan hal tersebut di atas, maka hipotesis yang dapat diajukan:

\section{$\mathrm{H}_{3}$ : Public Ownership berpengaruh positif terhadap Future Earnings Response Coefficient}

\section{Growth Opportunity dan Future Earnings Response Coefficient}

Penelitian yang memperlihatkan pengaruh Growth Opportunity terhadap Future Earnings Response Coefficient adalah penelitian Brown (2001) dan Murwaningsari (2013) yang menunjukkan bahwa adanya pengaruh positif antara kesempatan pertumbuhan terhadap Future Earnings Response Coefficient. Hal ini berarti perusahaan dengan kesempatan pertumbuhan yang semakin tinggi cenderung memiliki laba kejutan yang positif yang merupakan signal positif bagi investor di pasar modal yang pada akhirnya dapat meningkatkan harga saham perusahaan. Berdasarkan hal tersebut di atas, maka hipotesis yang dapat diajukan:

\section{$\mathrm{H}_{4}$ : Growth Opportunity berpengaruh positif terhadap Future Earnings Response Coefficient}

\section{Leverage dan Future Earnings Response Coefficient}

Penelitian yang memperlihatkan pengaruh Leverage terhadap Future Earnings Response Coefficient adalah penelitian Dhaliwal et al. (1991), Mulyani et al. (2007) dan Murwaningsari (2013) yang menunjukkan bahwa Leverage berpengaruh signifikan negatif terhadap Future Earnings Response Coefficient. Hal ini berarti perusahaan dengan tingkat hutang yang besar cenderung memiliki tingkat resiko yang tinggi sehingga potensi untuk bangkrut juga meningkat, sehingga dapat mengakibatkan informasi laba yang tercermin pada harga saham di pasar modal cenderung turun. Berdasarkan hal tersebut di atas, maka hipotesis yang dapat diajukan: 


\section{$\mathrm{H}_{5}$ : Leverage berpengaruh negatif terhadap Future Earnings Response Coefficient}

\section{Kerangka Pemikiran Teoretis}

Berdasarkan hipotesis di atas maka kerangka pemikiran teoretis penelitian ini dapat ditunjukkan dalam gambar 1 adalah:

Variabel Independen

$\underline{\text { Variabel Dependen }}$

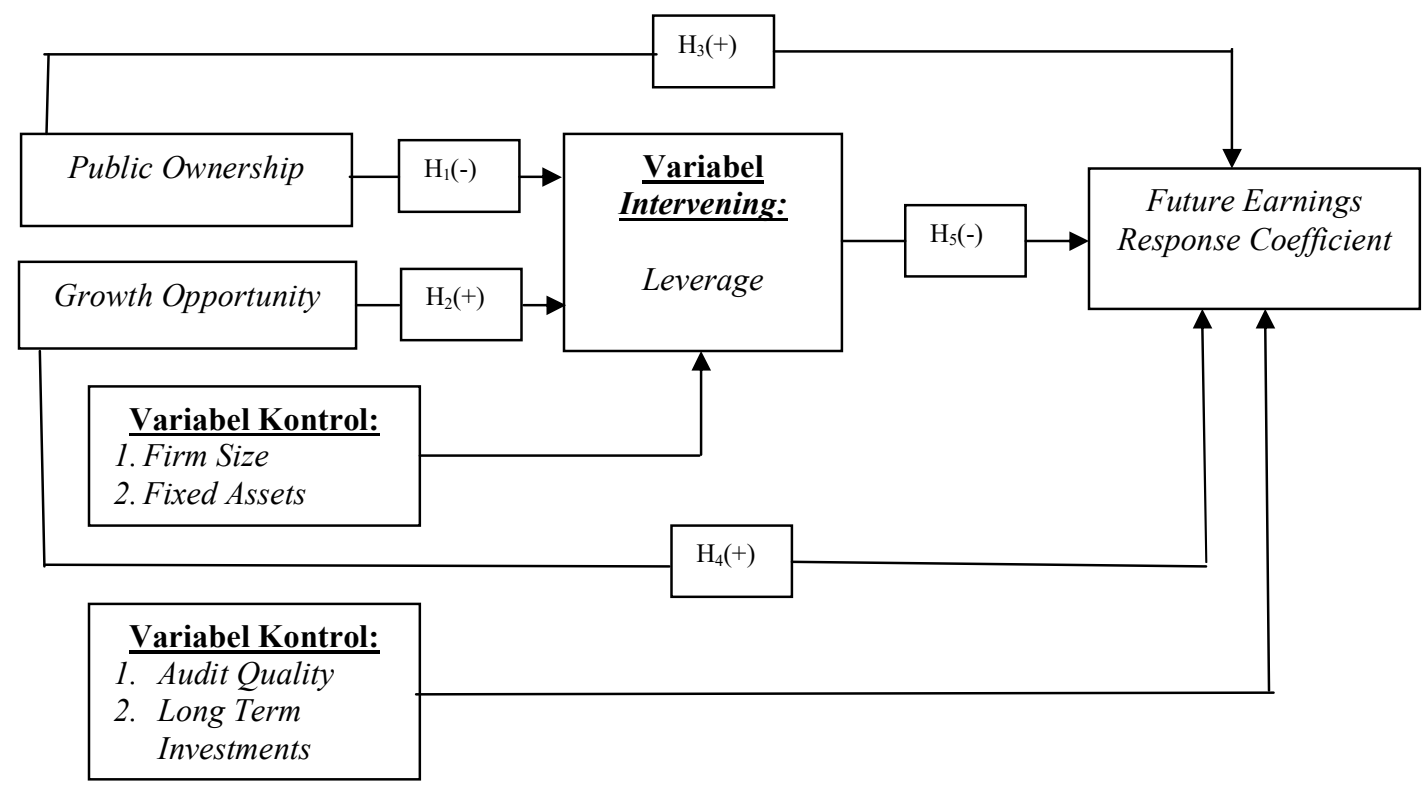

Gambar 1. Kerangka Pemikiran Teoretis

\section{METODE PENELITIAN}

\section{Data dan Sampel}

Data yang digunakan dalam penelitian ini adalah data perusahaan manufaktur yang tersedia di www.idx.co.id dan Indonesian Capital Market Directory (ICMD) pada tahun 2008 s/d 2015. Periode pengamatan penelitian ini adalah tahun 2008 s/d 2011, namun untuk perhitungan Future Earnings Response Coefficient dibutuhkan data dari tahun 2007 sampai dengan 2014. Pemilihan sampel dalam penelitian ini menggunakan metode purposive sampling, yaitu metode pemilihan sampel berdasarkan kriteria. Kriteria pemilihan sampel tersebut adalah (1) Perusahaan manufaktur yang terdaftar di Bursa Efek Indonesia pada tahun 2007-2014; (2) Perusahaan manufaktur yang menerbitkan laporan keuangan audited selama tahun 2007-2014; (3) Perusahaan manufaktur yang memiliki growth opportunity positif selama tahun 2007-2014; (4) Memiliki data lengkap untuk penelitian ini.

\section{Operasionalisasi Variabel}

1. Variabel Dependen. Variabel dependen dalam penelitian ini adalah Future Earnings Response Coefficient (FERC) dengan menggunakan model Collins et al. (1994) yang digunakan juga oleh Tucker \& Zarowin (2006) regression model of returns-future earnings response coefficient, sebagai berikut: $R_{t}=b_{0}+b_{1} X_{t-1}+b_{2} X_{t}+b_{3} X_{t 3}+b_{4} R_{t 3}+\varepsilon_{t}$

Dimana:

$R_{t}=$ Stock return tahun $\mathrm{t} ; X_{t-1}=$ EPS untuk tahun $\mathrm{t}-1$ dibagi dengan stock price pada awal tahun $\mathrm{t} ; X_{t}=$ EPS tahun $\mathrm{t}$ dibagi dengan stock price pada awal tahun $\mathrm{t} ; X_{t 3}=$ Jumlah EPS tahun $\mathrm{t}+1$ sampai dengan $\mathrm{t}+3$ dibagi dengan stock price awal tahun $\mathrm{t} ; R_{t 3}=$ Aggregate stock return pada tahun $\mathrm{t}+1$ sampai dengan $\mathrm{t}+3$. 
Koefisien pada laba yang telah lalu $\left(b_{1}\right)$ diprediksikan negatif, ERC $\left(b_{2}\right)$ diprediksikan positif, FERC $\left(b_{3}\right)$ diprediksikan positif dan koefisien pada future return $\left(b_{4}\right)$ diprediksikan negatif.

2. Variabel Independen. Variabel independen ini terdiri dari: a. Public Ownership dapat dihitung dari persentase (\%) kepemilikan saham publik yang dapat dilihat dari laporan keuangan tahunan perusahaan. Public Ownership ini mengacu pada penelitian (Lestari \& Hermanto, 2015); b. Growth Opportunity diukur dengan menggunakan pengukuran dari penelitian Prasetiono \& Pujiani (2012) yaitu Growth sama dengan (Net Sales(t) dikurang Net Sales (t-1)) dibagi Net Sales (t-1) dikali 100\%.

3. Variabel Intervening. Variabel intervening yang digunakan adalah penelitian ini adalah Leverage yang mengacu pada pengukuran Pandey (2002), yaitu Leverage yang diukur dengan menggunakan Debt to Assets Ratio (DAR = Total Hutang dibagi Total Aset).

4. Variabel Kontrol. Variabel kontrol ini terdiri dari variabel kontrol untuk Leverage, yaitu: (1) Firm Size diukur dengan menggunakan log natural dari total assets perusahaan (Prasetiono \& Pujiani, 2012); (2) Fixed Assets atau tangibility of fixed assets diukur dengan mengunakan proporsi aset tetap terhadap total assets perusahaan (Prasetiono \& Pujiani, 2012); dan variabel kontrol untuk Future Earnings Response Coefficient (FERC), yaitu: (1) Audit Quality merupakan variabel dummy, dimana variabel ini diukur berdasarkan kualitas atas Kantor Akuntan Publik yang melakukan audit terhadap perusahaan. Jika Kantor Akuntan Publik (KAP) adalah KAP Big Four, maka diberikan skor 1, dan skor 0 untuk sebaliknya (Hussainey, 2009); (2) Long Term Investment dalam penelitian ini menggunakan pengukuran dari Lee (2007) yaitu menggunakan Capital Intensity dan R\&D Intensity, tetapi dalam penelitian ini hanya menggunakan Capital Intensity (Long Term Investment $=$ Total Assets dibagi Net Sales) karena tidak semua perusahaan manufaktur yang terdaftar di Bursa Efek Indonesia mengungkapkan biaya penelitian dan pengembangannya (Murwaningsari, 2013).

\section{Metode Analisis Data}

Metode analisis data yang digunakan dalam penelitian ini adalah analisis jalur (path analysis). Analisis jalur dapat dilakukan dengan menggunakan Structure Equation Model (SEM), dengan pengolahan data menggunakan AMOS (Analysis of Moment Structures) versi 22. Penggunaan SEM dilakukan karena untuk menguji pengaruh langsung dan pengaruh tidak langsung, sehingga dilakukan dengan tahapan dari Hair et al. (2010) yaitu: (1) Ukuran sampel dalam estimasi dan interpretasi hasil SEM, sehingga sampel berkisar 100-200; (2) Melakukan uji normalitas; (3) Melakukan uji Multicolinearity dan Singularity; (4) dan melakukan uji kesesuaian model penelitian.

Model persamaan dalam penelitian ini terdiri dari 2 persamaan, persamaan ke 1 untuk model pengujian hipotesis 1 dan 2, sedangkan persamaan ke 2 untuk model pengujian hipotesis 3, 4 dan 5. Model persamaan tersebut adalah:

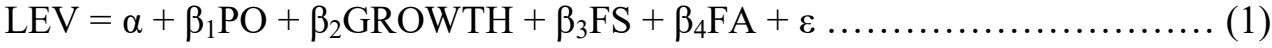

$\mathrm{FERC}=\alpha+\beta_{1} \mathrm{PO}+\beta_{2} \mathrm{GROWTH}+\beta_{3} \mathrm{LEV}+\beta_{4} \mathrm{AQ}+\beta_{5} \mathrm{LTI}+\varepsilon$

Dimana:

FERC = Future Earnings Response Coefficient; LEV = Leverage; PO = Public Ownership; GROWTH = Growth Opportunity; $\mathrm{AQ}=$ Audit Quality; LTI = Long Term Investment; FS = Firm Size; FA = Fixed Assets

\section{HASIL DAN PEMBAHASAN}

Sampel penelitian yang digunakan dalam penelitian ini adalah semua perusahaan yang terdaftar 
di Bursa Efek Indonesia pada tahun 2008-2011, telah mengeluarkan laporan keuangan audited tahun 2008-2011 dan memiliki data lengkap dalam penelitian ini selama tahun 2007 s/d 2014. Berdasarkan hasil purposive sampling untuk pengumpulan data penelitian ini, maka perusahaan manufaktur yang dijadikan sampel sebanyak 273 observasi (unbalance data).

Hasil dari pengujian statistik deskriptif diketahui dari 273 jumlah observasi, variabel Public Ownership (PO) memiliki nilai rata-rata yang lebih besar daripada variabel Growth Opportunity (GROWTH). Artinya perusahaan lebih banyak menggunakan Public Ownership daripada Growth Opportunity dalam memprediksi Future Earnings Response Coefficient. Tetapi Growth Opportunity memiliki standar deviasi sedikit lebih tinggi dibandingkan dengan Public Ownership, yang berarti Growth Opportunity memiliki varians tersebar. Audit quality memiliki median sebesar 0 yang menunjukkan bahwa perusahaan manufaktur yang terdaftar di Bursa Efek Indonesia menggunakan auditor bukan dari KAP Big Four.

Sebelum menganalisa hipotesis yang diajukan, terlebih dahulu dilakukan pengujian kesesuaian model (goodness-of-fit model). Berdasarkan keseluruhan perhitungan tingkat kesesuaian model menunjukkan hasil yang baik, nilai root mean square error of approximation (RMSEA) didapat hasil yang lebih besar dari 0,080 atau 0,103 >0,080. Syarat utamanya pada uji kesesuaian model adalah dengan melihat nilai chi-square. Hal ini dapat dilihat dari nilai chi-square 15,559 lebih besar dibandingkan dengan chi-square pembanding 9,487, Disamping itu nilai p-value 0,004 lebih kecil dari 0,05 (significant) dan kriteria absolute fit measures yang lain dapat dilihat dari nilai goodness-of-fit Index (GFI) yang lebih besar dari 0,90 atau GFI sebesar 0,986.

Adapun kriteria berdasarkan incremental fit measures dapat ditinjau dari nilai normed fit index (NFI) sebesar 0,946; turker-lewis index (TLI) sebesar 0,686; adjusted goodness-of-fit index (AGFI) sebesar 0,875; dan comparative fit index (CFI) sebesar 0,955. Sementara itu kriteria berdasarkan parsimonious fit measures yaitu nilai dari normed chi-square (CMIN/DF) sebesar 3,890 ( $\chi^{2}$ sebesar 15,559 dibagi DF sebesar 4) memenuhi ketentuan yang direkomendasikan yaitu batas bawah 1 atau batas atas 5. Dengan demikian secara keseluruhan model persamaan structural yang digunakan dapat diterima, hal ini dikarenakan 4 dari indikator pengukuran menyatakan model baik.

\section{Hasil Pengujian Hipotesis}

Hasil pengujian hipotesis 1 sampai dengan 5 didapatkan dari persamaan empiris yang dihasilkan yaitu:

$\mathrm{LEV}=0.116-0.014 \mathrm{PO}+0.265 \mathrm{GROWTH}+0.094 \mathrm{FS}+0.210 \mathrm{FA}+\varepsilon$

FERC $=0.135+0.139 \mathrm{PO}+0.119 \mathrm{GROWTH}-0.251 \mathrm{LEV}-0.038 \mathrm{AQ}-0.201 \mathrm{LTI}+\varepsilon$

Berdasarkan persamaan empiris di atas dapat diinterpretasikan sebagai berikut nilai konstanta $(\alpha)$ sebesar 0.116 menunjukkan bahwa apabila nilai Public Ownership, Growth Opportunity, Firm Size dan Fixed Assets adalah 0 (nol), maka nilai Leverage akan sebesar 0.116 satuan. Sedangkan nilai konstanta $(\alpha) 0.135$ menunjukkan bahwa apabila nilai Public Ownership, Growth Opportunity, Leverage, Audit Quality dan Long Term Investment adalah 0 (nol), maka nilai Future Earnings Response Coefficient akan sebesar 0.135 satuan. Hasil persamaan empiris ini ditunjukkan dalam tabel 1 dan 2.

Hasil hipotesis 1 dalam tabel 1 diperoleh $p$-value untuk $\mathrm{H}_{1}$ sebesar $0,806>$ alpha 0,05 dan koefisien regresi sebesar $-0,014$, maka $\mathrm{H}_{1}$ ditolak yang artinya tidak terdapat pengaruh Public Ownership terhadap Leverage. Hasil hipotesa pertama dalam penelitian ini tidak konsisten dengan penelitian Lestari \& Hermanto (2015) dan Ariyanto (2002), karena pemegang saham publik menggabungkan sahamnya menjadi satu tetapi tidak dapat diwakilkan kepada satu dewan komisaris yang turut memonitor secara ketat bagaimana kinerja perusahaan dalam mengelola saham-saham yang di miliki oleh pemegang saham publik. Perwakilan dari pemegang saham 
publik tidak mengutamakan kesejahteraan pemegang saham minoritas sehingga melemah hak suara akibat kepentingan antara pemegang saham mayoritas dan manajer perusahaan. Hal ini membuat Public Ownership tidak memiliki hak suara dalam memutuskan melakukan pinjaman atau tidak.

Hasil hipotesis 2 dalam tabel 1 diperoleh p-value untuk $\mathrm{H}_{2}$ sebesar $0,000<$ alpha 0,05 dan koefisien regresi sebesar 0,265, maka $\mathrm{H}_{2}$ diterima yang artinya terdapat pengaruh Growth Opportunity terhadap Leverage dengan arah positif. Hasil hipotesa kedua dalam penelitian ini konsisten dengan penelitian Oetama et al. (2008), Shaheen \& Malik (2012), dan Murwaningsari (2013). Growth Opportunity yang memberikan asset yang besar kepada perusahaan dapat memberikan jaminan atas pinjaman yang diberikan pihak lain kepada perusahaan. Hal ini berarti kesempatan pertumbuhan yang semakin tinggi akan mendorong perusahaan untuk melakukan investasi dengan mengandalkan pendanaan melalui hutang yang lebih besar.

Hasil hipotesis 3 dalam tabel 1 diperoleh p-value untuk $\mathrm{H}_{3}$ sebesar $0,016<$ alpha 0,05 dan koefisien regresi sebesar 0,139, maka $\mathrm{H}_{3}$ diterima yang artinya terdapat pengaruh Public Ownership terhadap Future Earnings Response Coefficient dengan arah positif. Hasil hipotesa ketiga dalam penelitian ini konsisten dengan penelitian Luo et al., (2006), Firth et al. (2007), Cohen \& Langberg (2009), dan Huang \& Wright (2015), bahwa Public Ownership yang memberikan kesempatan perusahaan meningkatkan kepercayaan publik dalam proporsi Public Ownership, sehingga dapat memberikan jaminan atas pinjaman yang diberikan pihak lain kepada perusahaan. Sehubungan dengan kesempatan perusahaan meningkatkan kepercayaan publik dalam proporsi Public Ownership, yang diprediksikan akan memberikan manfaat berupa laba kejutan di masa depan yaitu Future Earnings Response Coefficient.

Hasil hipotesis 4 dalam tabel 1 diperoleh p-value untuk $\mathrm{H}_{4}$ sebesar 0,045 < alpha 0,05 dan koefisien regresi sebesar 0,119, maka $\mathrm{H}_{4}$ diterima yang artinya terdapat pengaruh Growth Opportunity terhadap Future Earnings Response Coefficient dengan arah positif. Hasil hipotesa keempat dalam penelitian ini konsisten dengan penelitian Brown (2001) dan Murwaningsari (2013), yaitu adanya pengaruh positif antara kesempatan pertumbuhan terhadap Future Earnings Response Coefficient. Hal ini berarti perusahaan dengan kesempatan pertumbuhan yang semakin tinggi cenderung memiliki laba kejutan yang positif yang merupakan signal positif bagi investor di pasar modal yang pada akhirnya dapat meningkatkan harga saham perusahaan.

Hasil hipotesis 5 dalam tabel 1 diperoleh $p$-value untuk $\mathrm{H}_{5}$ sebesar $0,000<$ alpha 0,05 dan koefisien regresi sebesar -0,251, maka $\mathrm{H}_{5}$ diterima yang artinya terdapat pengaruh Leverage terhadap Future Earnings Response Coefficient dengan arah negatif. Hasil hipotesa kelima dalam penelitian ini konsisten dengan penelitian Dhaliwal et al. (1991) dan Murwaningsari (2013) menunjukkan bahwa adanya hubungan negatif dan signifikan antara Leverage dan Future Earnings Response Coefficient. Hal ini berarti perusahaan dengan tingkat hutang yang besar cenderung memiliki tingkat resiko yang tinggi sehingga potensi untuk bangkrut juga meningkat, sehingga dapat mengakibatkan informasi laba yang tercermin pada harga saham di pasar modal cenderung turun.

Hasil pengujian hipotesa di atas menunjukkan bahwa variabel yang memiliki pengaruh langsung ke Future Earnings Response Coefficient adalah variabel Public Ownership, Growth Opportunity dan Leverage, sedangkan variabel yang paling mempengaruhi langsung ke Future Earnings Response Coefficient adalah variabel Leverage dengan tingkat signifikansi 0,000. Sedangkan variabel yang memiliki pengaruh tidak langsung ke Future Earnings Response Coefficient melalui Leverage adalah variabel Growth Opportunity, sehingga variabel Growth Opportunity melalui Leverage inilah yang paling memiliki pengaruh tidak langsung terhadap Future Earnings Response Coefficient dengan tingkat signifikansi 0,000. Berikut ini merupakan hasil pengujian 
hipotesis dengan metode Structural Equation Modeling:

Tabel 1. Hasil Pengujian Pengaruh Langsung dan Tidak Langsung

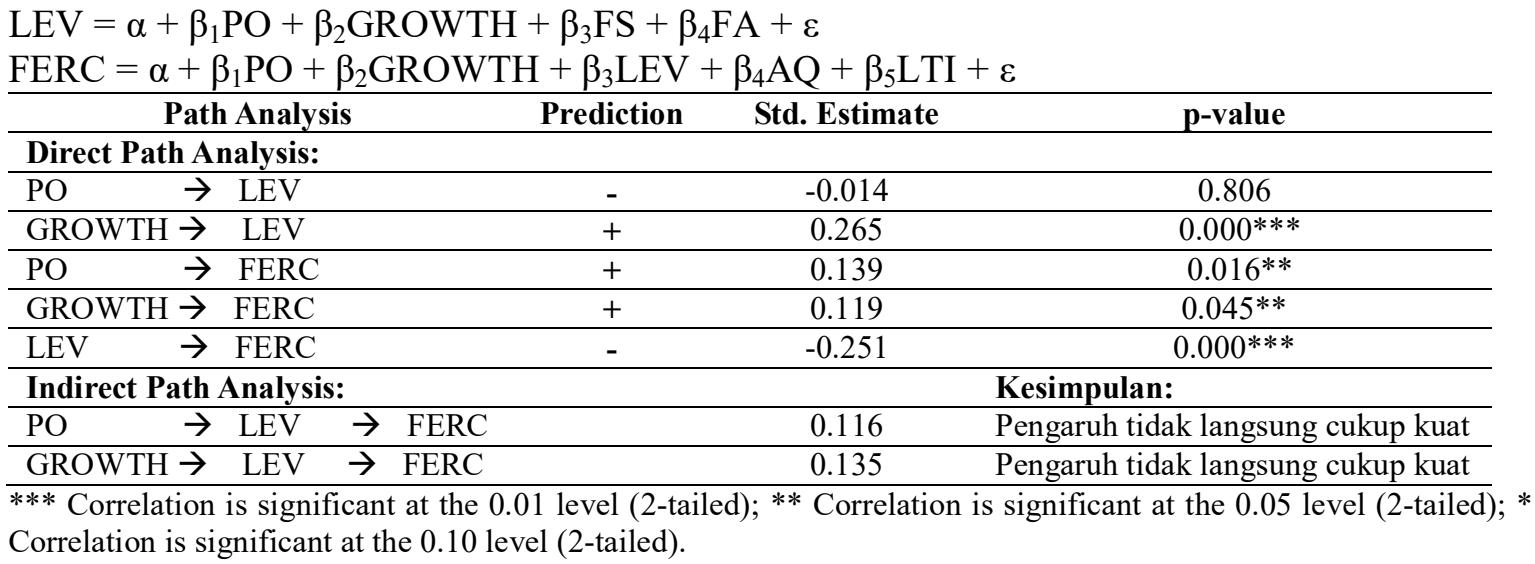

Pada model penelitian ini terdapat empat variabel kontrol yaitu Firm Size, Fixed Assets, Audit Quality, dan Long Term Investment. Hasil pengujian yang ditunjukkan dalam tabel 2 variabel kontrol, terdapat pengaruh positif yang signifikan Fixed Assets terhadap Leverage ( $p$-value $0,000<0,05)$ dan terdapat pengaruh negatif signifikan Long Term Investment terhadap Future Earnings Response Coefficient ( $p$-value 0,000 < 0,05) sesuai penelitian Murwaningsari (2013). Sementara Firm Size tidak berpengaruh signifikan terhadap Leverage, dan Audit Quality tidak berpengaruh signifikan terhadap Future Earnings Response Coefficient.

\section{Tabel 2. Hasil Pengujian Variabel Kontrol}

\begin{tabular}{|c|c|c|c|c|c|}
\hline \multicolumn{3}{|c|}{ Path Analysis } & \multirow{2}{*}{$\begin{array}{c}\text { Prediction } \\
+\end{array}$} & \multirow{2}{*}{$\frac{\text { Std. Estimate }}{0.094}$} & \multirow{2}{*}{$\begin{array}{c}\text { p-value } \\
0.118\end{array}$} \\
\hline $\mathrm{FS}$ & $\rightarrow$ & LEV & & & \\
\hline FA & $\rightarrow$ & LEV & + & 0.210 & $0.000 * * *$ \\
\hline $\mathrm{AQ}$ & $\rightarrow$ & FERC & + & -0.038 & 0,521 \\
\hline LTI & $\rightarrow$ & FERC & + & -0.201 & $0.000 * * *$ \\
\hline
\end{tabular}

\section{KESIMPULAN DAN SARAN}

\section{Kesimpulan}

Penelitian ini bertujuan untuk memperoleh bukti empiris Public Ownership, Growth Opportunity dan Leverage mempunyai pengaruh langsung terhadap Future Earnings Response Coefficient, serta bukti empiris Public Ownership, Growth Opportunity melalui Leverage mempunyai pengaruh tidak langsung terhadap Future Earnings Response Coefficient. Sampel yang digunakan untuk penelitian ini adalah 273 data observasi perusahaan manufaktur yang terdaftar di Bursa Efek Indonesia selama periode 2008-2011, dengan menggunakan data tahun 20072014. Berdasarkan hasil penelitian yang dilakukan dapat disimpulkan bahwa: (1) Public Ownership tidak berpengaruh terhadap Leverage; (2) Growth Opportunity berpengaruh positif terhadap Leverage (3) Public Ownership berpengaruh positif terhadap Future Earnings Response Coefficient; (4) Growth Opportunity berpengaruh positif terhadap Future Earnings Response Coefficient; (5) Leverage berpengaruh negatif terhadap Future Earnings Response Coefficient; (6) Variabel kontrol Leverage yaitu variabel Fixed Assets berpengaruh positif terhadap Leverage, tetapi variabel Firm Size tidak berpengaruh terhadap Leverage; (7) Variabel kontrol Future Earnings Response Coefficient yaitu Long Term Investment berpengaruh negatif 
terhadap Future Earnings Response Coefficient, tetapi variabel Audit Quality tidak berpengaruh terhadap Future Earnings Response Coefficient.

\section{Implikasi Manajerial}

Implikasi manajerial yang terdapat pada penelitian ini adalah: (1) Bagi investor, faktor Public Ownership belum tentu merupakan hal yang perlu diperhatikan yang mempengaruhi Leverage, karena ada Growth Opportunity dan faktor lain yang dapat mempengaruhi Leverage, sedangkan Public Ownership dan Growth Opportunity merupakan faktor yang mempengaruhi Future Earnings Response Coefficient; (2) Bagi perusahaan, agar lebih memperhatikan faktor-faktor yang dapat mempengaruhi Future Earnings Response Coefficient, agar membantu perusahaan dalam menarik para investor untuk berinvestasi diperusahaannya.

\section{Keterbatasan Penelitian}

Penelitian ini masih jauh dari sempurna karena memiliki beberapa keterbatasan, antara lain: (1) Jumlah sampel yang sedikit, sehingga hasil penelitian ini ada yang tidak konsisten dengan hasil penelitian sebelumnya yaitu Public Ownership terhadap Leverage; (2) Penelitian Future Earnings Response Coefficient merupakan penelitian yang jarang dilakukan di Indonesia, karena penelitian ini merupakan isu yang cukup baru.

\section{Saran}

Saran untuk penelitian selanjutnya adalah (1) Jumlah sampel diperbanyak yaitu sampel perusahaan non keuangan atau seluruh perusahaan yang terdaftar di Bursa Efek Indonesia; (2) Penelitian selanjutnya sebaiknya dikaitkan dengan variabel Voluntary Disclosure dan Real Earnings Management.

\section{REFERENSI}

Ariyanto, T. (2002). Pengaruh Struktur Pemegang Saham Terhadap Struktur Modal Perusahaan, Jurnal Manajemen Indonesia, 1(1), 64-71.

Brown, L. (2001). A Temporal Analysis of Earnings Surprises: Profits and Losses. Journal of Accounting Research, 39, 221-241.

Chen, J., Jiang, C. \& Lin, Y. (2014). What Determine Firm's Capital Structure in China?. Managerial Finance, 40(10), 1024-1039.

Chou, T. K., Cheng J. C. \& Lin, H. C. (2012). Customer Satisfaction, Future Earnings and Market Mispricing. Department of Accounting and Information Technology. National Chung Cheng University, Chiayi, Taiwan.

Cohen, D. A. \& Langberg, N. S. (2009). Venture Capital Financing and The Informativeness of Earnings. Asia-Pasific Journal of Accounting \& Economics, 16, 171-190.

Collins, D. W., Kothari, S. P. Shanken, J. \& Sloan, R. (1994). Lack of Timeliness and Noise as Explanations for the Low Contemporaneous Return-Earnings Association. Journal of Accounting and Economics, 18, 289-324.

Dhaliwal, D. S., Lee, K. J. \& Fargher, N. L. (1991). The Association between Unexpected Earnings and Abnormal Security Returns in the Presence of Financial Leverage. Contemporary Accounting Research, 8(1), 20-41.

Fahmi, I. (2014). Analisis Laporan Keuangan. Bandung: Penerbit Alfabeta.

Firth, M., Funf, P. M. Y. \& Rui, O. M. (2007). Ownership, Two-tier Board Structure, and The Informativeness of Earnings-Evidence from China. Journal of Accounting and Public Policy, 26, 463-496.

Hair, J. F., Black, W. C., Babin, B. J. \& Anderson, R. E. (2010). Multivariate Data Analysis. Seventh Edition. Pearson Prentice Hall. 
Huang W. \& Wright, B. (2015). Analyst Earnings Forecast Under Complex Corporate Ownership in China. Journal of International Financial Markets, Institutions \& Money, $35,69-84$.

Hussainey, K. (2009). The Impact of Audit Quality on Earnings Predictability. Managerial Auditing Journal, 24(4), 340-351.

Indrajaya, G., Herlina \& Setiadi, R. (2011). Pengaruh Struktur Aktiva, Ukuran Perusahaan, Tingkat Pertumbuhan, Profitabilitas dan Risiko Bisnis Terhadap Struktur Modal: Studi Empiris Pada Perusahaan Sektor Pertambangan yang Listing di Bursa Efek Indonesia Periode 2004-2007. Akurat Jurnal Ilmiah Akuntansi, 6(2).

Lee, J. (2007). Cross-sectional Determinants of the Extent to Which Stock Prices Lead Earnings. Disertation. School of Business, Hong Kong Baptist University, Hong Kong.

Lestari, S. A. \& Hermanto, S. B. (2015). Pengaruh Kepemilikan Saham dan Rasio Keuangan Terhadap Struktur Modal Perusahaan. Jurnal Ilmu \& Riset Akuntansi, 4(3), 1-21.

Luo, S., Courtenay, S. M. \& Hossain, M. (2006). The Effect of Voluntary Disclosure, Ownership Structure and Proprietary Cost on The Return-Future Earnings Relation. Pasific-Basin Finance Journal, 14, 501-521.

Mulyani, Asyik \& Andayani. (2007). Faktor-faktor yang mempengaruhi Earnings Response Coefficients pada Perusahaan yang Terdaftar di Bursa Efek Jakarta. JAAI, 11(1), 35-45.

Murwaningsari, E. (2013). Pengaruh Kesempatan Pertumbuhan dan Investasi Jangka Panjang Terhadap Leverage dan Future Earnings Response Coefficient. Media Riset Bisnis \& Manajemen, 13(1), 1-19.

Murwaningsari, E. (2014). Kepemilikan Institusional dan Kualitas Audit Terhadap Pengungkapan Informasi dan Future Earnings Response Coefficient. Jurnal Keuangan dan Perbankan, 18(2), 161-171.

Oetama, K., Deddy, M., Liliana \& Inggrid, W. (2008). Pengujian Teori Pecking Order Pada Kondisi High Uncertainty dan Low Uncertainty. Manajemen dan Bisnis, 7(1).

Pandey, I. M. (2002). Capital Market and Market Power. Indian Institute of Management Ahmedabad Vastrapur, Ahmedabad 380015, India.

Pradhana, E. P. M. \& Murwaningsari, E. (2014). Pengaruh Market Power dan Corporate Governance Terhadap Future Earnings Response Coefficient Pada Perusahaan di Bursa Efek Indonesia. E-Journal Akuntansi Trisakti, 1(1), 1-19.

Prasetiono \& Pujiani. (2012). Analisis Pengaruh Return On Assets, Sales Growth, Struktur Aset, Firm Size, dan Investment Opportunity terhadap Financial Leverage. Diponegoro Journal of Management, 1(1), 158-171.

Shaheen, S. \& Malik Q. A. (2012). The Impact of Capital Intensity, Size of Firm and Profitability on Debt Financing In Textile Industry of Pakistan. Interdisciplinary Journal of Contemporary Research in Business, 3(10).

Tucker, W. J. \& Zarowin, P. A. (2006). Does Income Smoothing Improve Earnings Informativeness?. The Accounting Review, 81(1), 251-270. 